\title{
University of Hawaii Cancer Center
}

National Cancer Institute

\section{Source}

National Cancer Institute. University of Hawail Cancer Center. NCI Thesaurus. Code C39348.

The University of Hawaii Cancer Center was founded in 1981 and became an NCldesignated cancer center in 1996. The Center's mission is to reduce the burden of cancer through research, education, and outreach, with an emphasis on the unique ethnic, cultural, and environmental characteristics of Hawaii and the Pacific. 